\title{
Frumkomin trefjunargallgangabólga á Íslandi 1992-2012
}

\author{
Hafsteinn Óli Guð̃nason ${ }^{1}$ læknir \\ Jón Örvar Kristinsson ${ }^{1}$ læknir \\ Óttar Már Bergmann ${ }^{1}$ læknir \\ Sigurður Ólafsson ${ }^{1}$ læknir \\ Jón Gunnlaugur Jónasson ${ }^{2,3}$ ææknir \\ Einar Stefán Björnsson ${ }^{1,3}$ læknir
}

${ }^{1}$ Meltingardeild, ${ }^{2}$ meinafræðideild Landspítala,

${ }^{3}$ æknadeild Háskóla Íslands.

Fyrirspurnum svarar Hafsteinn Óli Guðrnason, haddiog@gmail.com

\section{Inngangur}

Frumkomin trefjunargallgangabólga (primary sclerosing cholangitis, PSC) er langvinnur bólgusjúkdómur sem herjar á gallganga innan og utan lifrar. Orsakir sjúkdómsins eru ópekktar. Einkennandi fyrir sjúkdóminn er bólga og bandvefsmyndun í gallgöngum sem getur valdið á víxl prengingum og víkkunum í gallvegum sem líkjast perlufesti á myndum. ${ }^{1}$ Skorpulifur og lifrarbilun eru algengar afleiðingar pegar sjúklingur hefur gengið lengi með sjúkdóminn. ${ }^{2}$ Auk pess eru sjúklingar í aukinni áhættu að greinast með krabbamein í gallgöngum og ristli. ${ }^{3}$ Allt að 50\% sjúklinga purfa lifrarígræðslu eða deyja af völdum sjúkdómsins innan 10-15 ára frá greiningu, ýmist vegna prálátrar stíflu í gallgöngum vegna endurtekinnar gallgangabólgu, skorpulifrar og/eða vegna krabbameins í gallgöngum og/eða lifur. ${ }^{4}$ Sjúklingar með bólgusjúkdóma í meltingarvegi eru í aukinni áhættu að fá sjúkdóminn og pá sérstaklega sjúklingar með sáraristilbólgu. Pekkt er að 2-7,5\% af sjúklingum með sáraristilbólgu greinast með PSC á lífsleiðinni og um 50-80\% af sjúklingum með PSC greinast einnig með sáraristilbólgu, eða Crohns-sjúkdóm..$^{5-10}$ Meirihluti sjúklinga eru karlmenn greindir á prítugs- eða fertugsaldri. ${ }^{5}$ Faraldsfræðirannsóknir hafa sýnt nýgengi allt frá 0,41/100.000 til 1,30/100.000 á ári. ${ }^{6-11}$ Nýgengi er einna hæst í Skandinavíu (tafla I). Hins vegar er skortur á rannsóknum sem skoða faraldsfræði pessa sjúkdóms í lýðgrunduðu pýði og engin slík rannsókn hefur verið gerð hjá heilli pjóð. Engin rannsókn hefur áður verið gerð á faraldsfræði PSC á Íslandi.

Markmið okkar var pví að skoða nýgengi pessa sjúkdóms á Íslandi á árunum 1992-2012 ásamt pví hvað einkennir sjúklingahópinn og hvernig peim farnast.

DOI: 10.17992/lbl.2019.09.245

\section{Á G R I P}

\section{INNGANGUR}

Frumkomin trefjunargallgangabólga er langvinnur bólgusjúkdómur í gallvegum innan og/eða utan lifrar sem getur valdið skorpulifur, lokastigs lifrarbilun og leitt til lifrarígræðslu. Bólgusjúkdómar í meltingarvegi, fyrst og fremst sáraristilbólga, er algengur áhættupáttur. Hæsta nýgengi fullorðinna sem hefur verið birt var 1,21,3/100.000 í Noregi og Svípjóð og 60-76\% höfðu bólgusjúkdóm í meltingarvegi. Markmið pessarar fyrstu rannsóknar sjúkdómsins á Íslandi var að kanna faraldsfræði hans frá árunum 1992-2012 og afdrif sjúklinganna.

\section{AĐFERĐIR}

Leit var framkvæmd í gagnagrunnum Landspítala og Sjúkrahússins á Akureyri að sjúkdómsgreiningunni: K83.0, „Gallgangabólga“, frá 1992 til 2012. Að auki var gerð leit að sjúklingum með yfirferð á öllum gallvegaspeglunum og segulómunum af gallvegum sem framkvæmdar voru á Landspítala 1992-2012. Einnig var gerð textaleit bæði i gagnagrunnum beggja spítalanna og í gagnagrunni meinafræðinnar fyrir lifrarsýni.

\section{NIĐURSTÖĐUR}

Alls fundust 42 sjúklingar með sjúkdóminn innan umrædds tímabils. Miðgildi aldurs við greiningu var 34 ára, $67 \%$ voru karlkyns og 90\% fullorðnir ( $\geq 18$ ára). Međalnýgengi á ári var 0,69/100.000 manns á rannsóknartímabilinu. Alls $88 \%$ sjúklinga reyndust vera með bólgusjúkdóm í meltingarvegi, par af $89 \%$ sjúklinga með sáraristilbólgu. Sjö sjúklingar hafa verið greindir með krabbamein, par af fjórir með meinið í gallgöngum og einn í gallblöðru. Innan tímabilsins dóu 5 sjúklingar (12\%), 51 mánuði (miðgildi) frá greiningu og par af prír úr gallgangakrabbameini 51 mánuðum (miðgildi) frá greiningu. Prír (7\%) purftu lifrarígræðslu, par af einn í tvígang.

\section{ÁLYKTANIR}

Nýgengi á Íslandi reyndist lægra en i nágrannalöndum okkar í Skandinavíu. Pað er óljóst hvort pað stafar af vangreiningu tilfella og/eđa ađ sjúkdómurinn sé sjaldgæfari á Íslandi en í Noregi og Svípjóð. Alls $7 \%$ purftu á lifrarígræðslu að halda og $12 \%$ dóu úr sjúkdómnum, aðallega vegna gallgangakrabbameins.

\section{Skammstafanir}

ALP = Alkalískur fosfatasi

ERCP = Gallgangaspeglun (endoscopic retrograde cholangiopancreatography) Gamma-GT = Gamma-glútamýl transferasi

MRCP = segulómun af gallgöngum (magnetic resonance cholangiopancreatography) ICD = ICD-10 Albjóðleg tölfræðiflokkun sjúkdóma (International classification of disease) $\mathrm{IQR}=$ fjórðungaspönn (interquartile range)

$\mathrm{PBC}=$ Frumkomin gallskorpulifur (primary biliary cholangitis) . PSC = Frumkomin trefjunargallgangabólga (primary schlerosing cholangitis) UDCA = Ursodeoxycholic sýra 
Tafla I. Nýgengi, kyn, aldur og hlutfall bólgusjúkdóma i görn hjá PSC-sjúklingum samkvæmt fyrri rannsóknum.

\begin{tabular}{|c|c|c|c|c|c|c|}
\hline Höfundar, ár & Fjöldi sjúlklinga & Nýgengi/100.000 & $\begin{array}{c}\text { Hlutfall karlar } \\
\%\end{array}$ & $\begin{array}{l}\text { Aldur við } \\
\text { greiningu }\end{array}$ & $\begin{array}{c}\text { Bólgusjúkdómar i } \\
\text { meltingarvegi \% }\end{array}$ & Land \\
\hline Boberg et al. $1998^{11}$ & 17 & 1,3 & $\mathrm{x}$ & $\mathrm{x}$ & $\mathrm{x}$ & Noregur \\
\hline Bambha et al. $2003^{6}$ & 22 & 0,9 & 68 & 40 ára (m) & 73 & Bandaríkin \\
\hline Kingham et al. $2004^{7}$ & 53 & 0,9 & 62 & 52 ára (M) & 62 & Bretland \\
\hline Kaplan et al. $2007^{8}$ & 49 & 0.9 & 55 & 41 árs (M) & 74 & Kanada \\
\hline Card et al. $2008^{9}$ & 149 & 0,4 & 64 & 55 ára $(m)$ & 48 & Bretland \\
\hline Lindkvist et al, $2010^{10}$ & 199 & 1,2 & 71 & 39 ára (M) & 76 & Svípjóð \\
\hline Guðnason et al, 2019 & 42 & 0,7 & 67 & 34 ára (M) & 88 & Ísland \\
\hline
\end{tabular}

$\mathrm{x}=$ vantar tölur, $\mathrm{m}=$ meðaltal, $\mathrm{M}=$ miðgildi

\section{Efniviður og aðferðir}

Um er að ræða lýsandi afturskyggna rannsókn sem náði til allra Íslendinga sem greindust með PSC á 21 árs tímabili frá 1. janúar 1992 til 31. desember 2012. Ekki er til sértækt ICD-10 greiningarnúmer fyrir pennan sjúkdóm, en eins og í fyrri rannsóknum, sem allar hafa verið afturskyggnar, ${ }^{8,10}$ var gerð leit að ICD-10 greiningunni K83.0 "gallgangabólga" í sjúkraskrárkerfum Landspítala og Sjúkrahússins á Akureyri. Pennan sjúkdómsgreiningarkóða ætti að nota hjá pessum sjúklingum við útskrift af spítala eða við komu á göngudeild. Ekki er hægt með vissu að gera ráð fyrir að svo hafi verið og að auki tíðkaðist ekki í byrjun rannsóknartímabilsins að setja sjúkdómsgreiningar við komu á göngudeild. Pess vegna var að auki leitað annarra leiða til að finna pessa sjúklinga.

Gerð var textaleit í Sögukerfi Landspítala og Sjúkrahússins á Akureyri. Par sem íslenska heitið „frumkomin trefjunargallgangabólga“ er ekki notað í daglegu tali né í skráningu gagna purfti að notast við leitarskilyrðin "primary sclerosing cholangitis", „sclerosing cholangitis“ og „PSC“. Að auki var gerð textaleit í gagnagrunni meinafræðideildar Landspítala. Að lokum var leitað eftir öllum aðgerðarkóðum fyrir gallgangaspeglanir (ERCP) og segulómunum af gallgöngum (MRCP) frá árunum 1992-2012 í gagnagrunni röntgendeildar og speglunardeild Landspítala. Til að minnka líkur á að missa af sjúklingum sem hafa fengið greiningu utan Landspítala og Sjúkrahússins á Akureyri voru sjálfstætt starfandi sérfræðingar í meltingarfærasjúkdómum spurðir hvort peir hefðu vitneskju um slíka sjúklinga í peirri viðleitni að ná til allra. Pegar búið að var að finna einstaklinga með sjúkdóminn var upplýsinga aflað úr sjúkraskrám peirra. Upplýsinga var aflað um aldur við greiningu, kyn, einkenni við greiningu, blóðprufur við greiningu, meðferð, lifrarígræðslur, aðrar greiningar, lifun og dánarorsök. Skilgreiningarmerki fyrir sjúkdóminn eru vel pekkt og stuðst var við svokölluð Mayo-skilgreiningarmerki, pað er 1) blóðprufur sem sýna fram á hækkun á lifrarprófum (sérstaklega áhrif á gallgöng), 2) merki um PSC-sjúkdóm á myndrannsóknum eða í lifrarsýni, og 3) engin merki um aðra orsök fyrir trefjunargallgangabólgu (secondary sclerosing cholangitis). ${ }^{6}$ Ef pessi gögn vantaði frá greiningu sjúklings var ákveðið að treysta á greiningarhæfni pess meltingarlæknis sem greindi sjúkling. Upplýsingum um sjúklingana var safnað fram til 31. desember 2016 með pví markmiði að sjá hvernig sjúklingum vegnaði yfir lengra tímabil, sérstaklega með tilliti til peirra sjúklinga sem greindust í lok rannsóknartímabils.

Upplýsingar sem fengust við gagnasöfnun voru skráðar í Microsoft Excel og unnið úr peim í sama forriti ásamt IBM SPSS Statistics 20. Mannfjöldatölur fyrir hvert ár rannsóknartímabilsins voru fengnar af vefsíðu Hagstofu Íslands.

Öll tilskilin leyfi fyrir rannsókninni voru fengin hjá vísindasiðanefnd, Persónuvernd, Landspítala og Sjúkrahúsinu á Akureyri (leyfi 10-132-V2).

\section{Niðurstöður}

\section{Rannsóknarpýði}

Könnuð voru gögn 480 sjúklinga sem fengu greininguna K83.0 „gallgangabólga“, 9 sjúklinga í gagnagrunni meinafræðideildarinnar, 19 sjúklinga með jákvæða textaleit og að lokum var farið í gegnum gögn 3961 sjúklings sem hafði farið í ERCP/MRCPrannsóknir. Alls uppfylltu 42 sjúklingar greiningarskilmerkin fyrir sjúkdóminn og greindust frá byrjun ársins 1992 til ársloka 2012. Af pessum 42 voru einungis fjögur börn (7, 13, 15 og 16 ára). Kynjahlutfall var 67\% karlmenn ( $n=28)$ og 33\% konur ( $n=14)$. Miðgildi aldurs við greiningu var 34 ára (fjórðungaspönn (interquartile range, spönn 21-44 ára). Miðgildi aldurs karla við greiningu var 32 ár (spönn 21-39 ára) og kvenna 43 ár (spönn 28-58 ára). Аð meðaltali greindust tveir á ári en flestir greindust árið 2011 (8 sjúklingar, mynd 1). Meðalnýgengi á rannsóknartímabilinu var 0,69/100.000 miðað við tölur frá Hagstofu Íslands fyrir árin 1992-2012. ${ }^{12}$ Nýgengi fullorðinna ( $\geq 18$ ára) var $0,85 / 100.000$ og nýgengi barna $(<18$ ára) einungis $0,24 / 100.000$.

\section{Einkenni}

Helstu einkenni við greiningu samkvæmt sjúkraskrám voru kviðverkir (29\%), kláði $(24 \%)$, gula (21\%), niðurgangur $(10 \%)$, preyta (10\%) og pyngdartap (5\%). Upplýsingar skorti um einkenni við greiningu hjá 15 sjúklingum. 
Tafla II. Blóðprufurniðurstöður við greiningu og fjöldi sjúklinga par sem pær blóðprufur mátti finna.

\begin{tabular}{lcccc}
\hline Blóðprufur & $\begin{array}{c}\text { Fjöldi } \\
\text { sjúklinga }\end{array}$ & Miðgildi & $\begin{array}{c}\text { Fjórðungaspönn } \\
(\mathrm{IQR})\end{array}$ & Viðmiðunargildi \\
\hline ALP & 28 & $256 \mathrm{U} / \mathrm{L}$ & $143-638 \mathrm{U} / \mathrm{L}$ & $35-105 \mathrm{U} / \mathrm{L}$ \\
\hline ALAT & 30 & $118 \mathrm{U} / \mathrm{L}$ & $66-221 \mathrm{U} / \mathrm{L}$ & $\begin{array}{c}\mathrm{KK} 10-70 \mathrm{U} / \mathrm{L} \\
\mathrm{Kvk} \mathrm{10-45} \mathrm{U/L}\end{array}$ \\
\hline ASAT & 31 & $73 \mathrm{U} / \mathrm{L}$ & $50-108 \mathrm{U} / \mathrm{L}$ & $\begin{array}{c}\mathrm{KK} 10-45 \mathrm{U} / \mathrm{L} \\
\mathrm{Kvk} \mathrm{10-35} \mathrm{U/L}\end{array}$ \\
\hline Gamma-GT & 31 & $310 \mathrm{U} / \mathrm{L}$ & $198-485 \mathrm{U} / \mathrm{L}$ & $\begin{array}{c}\mathrm{KK}<115 \mathrm{U} / \mathrm{L} \\
\mathrm{Kvk}<75 \mathrm{U} / \mathrm{L}\end{array}$ \\
\hline Bilirubín & 24 & $29 \mu \mathrm{mol} / \mathrm{L}$ & $9-51 \mu \mathrm{mol} / \mathrm{L}$ & $5-25 \mu \mathrm{mol} / \mathrm{L}$ \\
\hline Albúmín & 18 & $38 \mathrm{~g} / \mathrm{L}$ & $35-43 \mathrm{~g} / \mathrm{L}$ & $36-45 \mathrm{~g} / \mathrm{L}$ \\
\hline Kreatínín & 26 & $71 \mu \mathrm{mol} / \mathrm{L}$ & $60-80 \mu \mathrm{mol} / \mathrm{L}$ & $50-100 \mu \mathrm{mol} / \mathrm{L}$ \\
\hline
\end{tabular}

Blóðprufur við greiningu

Skráð voru lifrarpóf (alkalískur fosfatasi (ALP), alanín amínótransferasi (ALAT), aspartat amínótransferasi (ASAT), gamma-glútamýl transferasi (gamma-GT), bilirúbín og albúmín) við greiningu ásamt lípasa og kreatíníni. Ekki fundust blóðpróf við greiningu hjá 9 einstaklingum. Pau gildi sem voru mest áberandi hækkuð hjá sjúklingum voru ALP með miðgildið 256 U/L (spönn 143-638 U/L) og gamma-GT 310 U/L (spönn 198-485 U/L). IgG4var mælt í 9 sjúklingum (21\%) og var innan eðlilegra marka hjá peim öllum (0,02-1,25 g/L)) og pví ekki grunur um IgG4-orsakaðan gallgangasjúkdóm hjá peim sjúklingum. Sjá frekari blóðprufuniðurstöður í töflu II.

\section{Bólgusjúkdómar í meltingarvegi}

Meirihluti sjúklinga reyndist vera með bólgusjúkdóm í meltingarvegi, eða 37 sjúklingar (88\%), par af 27 karlmenn (73\%). Flestir voru með sáraristilbólgu, 33 sjúklingar (79\%), par af 25 karlmenn (76\%). Prír (7\%) voru með Crohns-sjúkdóm, par af tveir karlmenn. Ein kona var með „ótilgreindan bólgusjúkdóm í meltingarvegi“. Dreifing, alvarleiki og meðferð bólgusjúkdóms voru ekki skoðuð.

\section{Dreifing sjúkdóms}

Sjúkdómnum er oft skipt eftir pví hvort hann sé í stærri gallgöngum (sjáanlegur á myndrannsóknum) eða í smáum gallgöngum, einungis sýnilegur pegar vefsýni úr lifur er skoðað (small-duct PSC). Staðfest var að 27 (64\%) sjúklinganna höfðu farið í ERCPrannsókn, 33 (79\%) í MRCP-rannsókn og úr 26 (62\%) sjúklingum fundust lifrarsýni. Í pessari rannsókn voru 34 (81\%) sjúklingar með breytingar í stærri gallgöngum, sjáanlegt í ERCP og/eða MRCP. Fjórir sjúklingar (10\%) voru einungis með sjúkdóm í smærri gallgöngum, staðfest með vefjagreiningu úr lifur. Óvíst var með dreifingu hjá fjórum sjúklingum par sem gögn skorti.

\section{Meðferð}

Algengt er að sjúklingar með sjúkdóminn fái sýkingar og stíflur í gallvegi og purfi pví inngrip par sem stoðnet er sett í gallvega- speglun. Alls höfðu 16 sjúklingar (38\%) fengið stoðnet eftir greiningu. Meðferð með ursodeoxychol-sýru (UDCA) var reynd hjá 19 sjúklingum (45\%) en í byrjun árs 2010 voru einungis 8 sjúklingar (19\%) ennpá á lyfinu. Einn peirra sem er ennpá á lyfinu er með svokallað skörunarheilkenni (overlap syndrome), par sem hann var með bæði PSC og frumkomna gallskorpulifur (primary biliary cholangitis, $\mathrm{PBC}$ ).

\section{Lifrarígræðsla}

Í lok rannsóknartímabilsins höfðu einungis prír sjúklingar (7,1\%) farið í lifrarígræðslu. Einn sjúklingur fór í ígræðslu vegna versnandi skorpulifrar, einn vegna versnandi skorpulifrar ásamt endurteknum blæðingum úr bláæðagúlum í vélinda og sá priðji vegna endurtekinnar gallvegastíflu og vaxandi gulu. Sá síðastnefndi purfti ígræðslu í tvígang. Miðgildi tíma frá greiningu að aðgerð var 67 mánuðir.

\section{Lifun og afleiðingar sjúkdóms}

Á tímabilinu, frá 1. janúar 1992 til 31. desember 2016, hafa 7 sjúklingar verið greindir með krabbamein, fjórir með krabbamein í gallgöngum, einn í gallblöðru, einn með flögupekjukrabbamein í húð og einn með B-eitilfrumukrabbamein tveimur árum áður en hann greindist með gallgangasjúkdóminn. Af peim fjórum sjúklingum sem greindust með krabbamein í gallgöngum eru prír látnir úr krabbameininu en einn talinn læknaður eftir aðgerð og lyfjameðferð í kjölfarið. Fimm sjúklingar (12\%) dóu á tímabilinu um 51 mánuði (miðgildi) (spönn 41-125 mánuðir) frá greiningu. Allir 5 dóu úr afleiðingum sjúkdómsins. Dánarorsök priggja sjúklinga (tveir karlar og ein kona) var gallgangakrabbamein 51 mánuðum (miðgildi) frá greiningu. Einn (karl) lést af völdum lungnabólgu í kjölfar lifrarbilunar 170 mánuðum frá greiningu og sá síðasti (kona) úr blæðingu frá bláæðagúl í vélinda 47 mánuðum frá greiningu. Með pví að nýta tölur yfir meðalnýgengi gallgangameins samkvæmt Krabbameinsskrá Íslands gátum við reiknað áhættu okkar sjúklingahóps sem er 162 sinnum líklegri til að greinast með gallgangamein en almennt pýði á Íslandi. ${ }^{13}$

\section{Umræður}

\section{Nýgengi}

Nýgengi PSC á Íslandi (0,69/100.000) reynist lægra en í Svípjóð $(1,22 / 100.000)$ og Noregi (1,31/100.000).10,11 Í peim rannsóknum voru hins vegar einungis fullorðnir sjúklingar en okkar rannsókn náði til allra aldurhópa. Einungis tvær rannsóknir hafa einnig náð til barna með sjúkdóminn. ${ }^{8,9}$ Nýgengi var talsvert lægri fyrir börn í okkar rannsókn samanborið við fullorðna, sem má einnig sjá í erlendum rannsóknum (0,24/100.000 hér og 0,23/100.000 erlendis). ${ }^{8}$ Nýgengi fullorðinna ( $\geq 18$ ára) á Íslandi var $0,85 / 100.000$ sem er svipað nýgengi og í Bandaríkjunum, Bretlandi og Kanada (tafla I).$^{6-8}$ Okkar rannsókn var með aðeins lægri meðalaldur við greiningu (34 ára) en fyrri rannsóknir hafa sýnt aldur við greiningu vera um 39-55 ára. ${ }^{6-10}$ Pegar einungis er tekið tillit til fullorðinna, í okkar rannsókn, hækkar meðalaldur og miðgildi aldurs einungis 
upp í 35 ár. Hlutfall karlmanna er pó svipað (67\%) samanborið við aðrar rannsóknir (48-71\%). ${ }^{6-10}$

Bólgusjúkdómar í meltingarvegi

Niðurstöður fyrri rannsókna hafa sýnt að mikill meirihluti sjúklinga hefur sáraristilbólgu eða Crohns-sjúkdóm pegar peir greinast. ${ }^{6-10}$ Hátt hlutfall sjúklinga okkar var með bólgusjúkdóm í meltingarvegi og er pað með pví hæsta sem lýst hefur verið og pá sérstaklega varðandi sáraristilbólgu. Erfitt er að túlka hvers vegna, en hugsanlega endurspeglar pað gott eftirlit með sjúklingum með sáraristilbólgu eða Crohns-sjúkdóm. Hjá pessum sjúklingahópi er reglulega fylgst með lifrarprófum bæði vegna lyfjameðferðar og vegna hættu á að próa með sér PSC. Í okkar sjúklingahópi var pað yfirleitt hækkun ALP í blóði sem vakti grun um sjúkdóminn og sjúklingur pá sendur í frekari rannsóknir. Áður en segulómun af gallvegum kom til var yfirleitt gert ERCP til greiningar, en nú á síðari árum byggir greiningin á MRCP og stundum á vefjasýnum úr lifur ef myndgreining nægir ekki. ${ }^{14}$ Pannig geta sjúklingar greinst með smásæja bólgu (small-duct PSC) sem parfnast lifrarsýnis til greiningar. Okkar niðurstöður leiddu í ljós að 10\% sjúklinga voru með smásæja bólgu, sem er svipað og í öðrum rannsóknum. ${ }^{15}$ Pær niðurstöður benda til að okkar sjúklingar hafi verið rannsakaðir ítarlega eða að minnsta kosti jafn vel og sjúklingar í öðrum vestrænum löndum. Hins vegar má einnig koma með pá kenningu að einstaklingar sem eru með PSC án bólgusjúkdóms í meltingarvegi séu vangreindir par sem ekki er reglulega fylgst með lifrarprófum hjá peim sjúklingahópi fyrir greiningu. Einnig er mögulegt að sá sjúklingahópur sé líklegri til að fá ranga greiningu, til dæmis PBC í stað PSC, par sem tenging lækna milli PSC og bólgusjúkdóma í meltingarvegi er sterk.

\section{Lyfjameðferð}

Lyfjameðferð með UDCA var mikið rannsökuð sem meðferð til að bæta horfur sjúklinganna í lok síðustu aldar og fyrsta áratug pessarar og reyndist lækka lifrarpróf. ${ }^{16}$ Stór rannsókn sýndi hins vegar fram á að PSC-sjúklingar á UDCA-meðferð í háum skömmtum hefðu verri horfur en peir sem fengu lyfleysu og pví hefur dregið mjög úr meðferð með pessu lyfi og henni verið hætt í flestum tilfellum. ${ }^{17}$ Pessi breytta stefna í lyfjameðferð endurspeglast vel í okkar sjúklingahópi par sem einungis 8 af peim 19 sjúklingum sem fengu UDCA-meðferð voru ennpá á lyfinu árið 2010. Auk pess var einn peirra með skörunarheilkenni og pví einnig með PBC par sem UDCA er kjörmeðferð. ${ }^{18}$

\section{Krabbameinsáhætta}

Aukin hætta á krabbameini, sérstaklega í gallvegum, er vel pekkt hjá PSC-sjúklingum. Helst er um að ræða gallgangakrabbamein en lifrarkrabbamein er einnig pekkt. Líkt og í okkar rannsókn hafa fyrri rannsóknir sýnt að pessir sjúklingar eru allt að 161-177 sinnum líklegri (162 sinnum líklegri í pessari rannsókn) en almennt pýði til að greinast með krabbamein í lifur og/eða gallgöngum.,19 Mikilvægt er pví að skima reglulega fyrir krabbameini í pessum sjúklingum með árlegum myndrannsóknum. ${ }^{20}$ Sjúklingar með

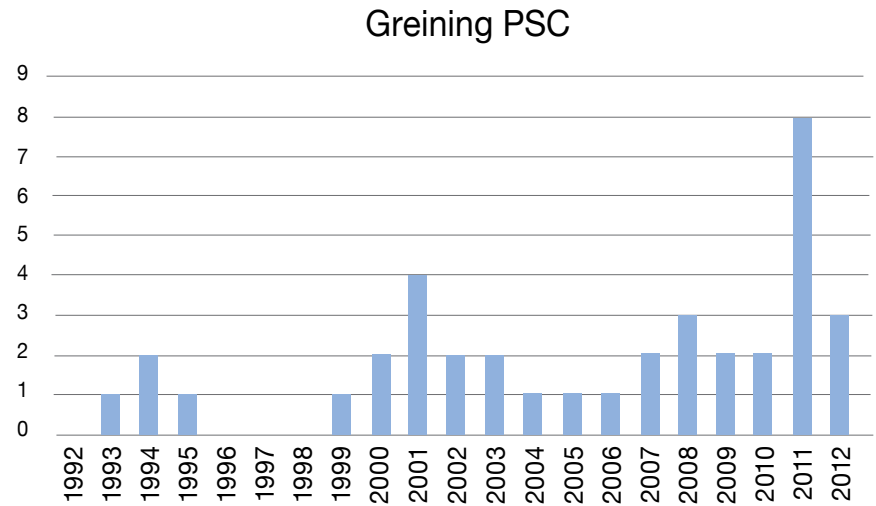

Mynd 1. Fjöldi sjúklinga greindir á hverju ári 1992-2012.

sáraristilbólgu eru með aukna áhættu á að fá ristilkrabbamein og eldri rannsóknir hafa sýnt fram á að greining PSC-sjúkdóms auki talsvert á pá áhættu. ${ }^{3,21}$ Nýlegri rannsóknir hafa pó ekki allar náð að sýna fram á pessa auknu áhættu. ${ }^{19}$ Við höfum ekki heldur náð að sýna fram á pessa auknu áhættu par sem enginn af okkar sjúklingum var greindur með ristilkrabbamein. Par sem við erum ekki með gögn úr ristilspeglunum sjúklinga er óvíst hversu margir sjúklingar hafa verið með ristilsepa sem hafa verið fjarlægðir og par með komið í veg fyrir ristilkrabbamein síðar meir. Allt аð 20\% af PSC-sjúklingum erlendis sem purfa lifrarígræðslu eru vegna krabbameins í lifur og/eða gallgöngum. ${ }^{22}$ Í okkar rannsókn greindust 10\% með krabbamein í gallgöngum (milli 5-20\% í öðrum rannsóknum) ${ }^{19,23,24}$ en enginn peirra gekkst undir lifrarígræðslu.

\section{Lifun og lifrarígræðsla}

Lýðgrundaðar rannsóknir hafa sýnt fram á að um 12\% PSC-sjúklinga purfi lifrarígræðslu. ${ }^{19}$ Einungis $7 \%$ af okkar sjúklingum fengu lifrarígræðslu á rannsóknartímabilinu en taka parf tillit til pess að einn peirra purfti ígræðslu í tvígang. Einnig er tími frá greiningu að lifrarígræðslu lengri hér en erlendis (67 mánuður hjá okkur á móti 24 mánuðum erlendis).$^{19}$ Óvíst er hvers vegna færri fá lifrarígræðslu á Íslandi og tími að aðgerð er lengri en hugsanlega er aðgangur að lifrarígræðslu hér erfiðari (lifrarígræðslur eru ekki framkvæmdar á Íslandi). Ekki var sérstaklega skráo hversu margir sjúklingar höfðu fengið lifrarbilun og jafnað sig án lifrarígræðslu en enginn var með lifrarbilun í lok tímabilsins. Pegar lifun er skoðuð í erlendum rannsóknum eru niðurstöður okkar svipaðar. Sænsk lýðgrunduð rannsókn á PSC-sjúklingum sýndi fram á að 13\% sjúklingar dóu 48 mánuðum frá greiningu (12\% og 51 mánuður í okkar rannsókn). ${ }^{19}$

\section{Styrkleikar og veikleikar}

Helstu veikleikar pessarar rannsóknar eru að ekki er til sértækur ICD-kóði fyrir sjúkdóminn. Ekki er hægt að treysta á að sjúklingar sem greinast með PSC hafi fengið greininguna K83.0, "gallgangabólga“. Petta eykur hættu á að missa af sjúklingum með greiningu sem getur haft talsverð áhrif á nýgengistölur fyrir svona lítið pýði. Til að vega á móti pessu var gerð ítarleg leit með fleiri en einni aðferð, sem verður að teljast styrkleiki fyrir pessa rannsókn. 
Einnig geta sjúklingar hafa fengið greiningu utan Landspítala eða Sjúkrahússins á Akureyri. Par sem við skoðuðum öll vefjasýni með greiningunni og öll ERCP og MRCP sem gerð voru innan tímabilsins, auk pess sem sjálfstætt starfandi sérfræðingar í meltingarfærasjúkdómum voru spurðir, er ólíklegt að við höfum misst af peim sjúklingum. Par sem pessi rannsókn var afturskyggn og fyrri hluti rannsóknartímabilisins er áđur en rafræn skráning hófst, vantaði ýmis gögn. Fyrst og fremst skorti skráningu á einkennum við greiningu. Rannsóknarpýðið nær yfir alla Íslendinga og pví er ekki mikil hætta á að sjúklingar "týnist“ vegna brottflutnings eins og oft er raunin í erlendum faraldsfræðilegum rannsóknum sem eru gerðar í stærri löndum. Ákveðið óöryggi fylgir faraldsfræðilegum rannsóknum á sjaldgæfum sjúkdómum eins og PSC par sem aukin greining á einu ári (eins og til dæmis árið 2011 samkvæmt mynd 1) getur haft stór áhrif á nýgengitölur. Aftur á móti nær rannsókn okkar yfir langt tímabil sem minnkar áhrif slíkra stórra breytinga.

\section{Samantekt}

Petta er fyrsta faraldsfræðirannsóknin á PSC sem nær til heillar pjóðar samkvæmt okkar vitneskju. Nýgengi á Íslandi reyndist lægra en í nágrannalöndum okkar í Skandinavíu. Pað er óljóst hvort pað stafar af vangreiningu tilfella og/eða að sjúkdómurinn sé sjaldgæfari hér á landi. Hlutfall PSC-sjúklinga með bólgusjúkdóm í meltingarvegi er með pví hæsta sem lýst hefur verið, og pá sérstaklega sáraristilbólgu.

\section{Heimildir}

1. Björnsson E, Chapman RW. Sclerosing cholangitis. Curr Opin Gastroenterol 2003; 19: 270-5.

2. Chapman RW, Arborgh BA, Rhodes JM, Summerfield JA Dick R, Scheuer PJ, et al. Primary sclerosing cholangitis: a review of its clinical features, cholangiography, and hepatic histology. Gut 1980; 21: 870-7.

3. Bergquist A, Ekbom A, Olsson R, Kornfeldt D, Loof L, Danielsson A, et al. Hepatic and extrahepatic malignancies in primary sclerosing cholangitis. J Hepatol 2002; 36: 3217.

4. Hirschfield GM, Karlsen TH, Lindor KD, Adams DH Primary sclerosing cholangitis. Lancet 2013; 382: 1587-99.

5. Molodecky NA, Kareemi H, Parab R, Barkema HW, Quan H, Myers RP, et al. Incidence of primary sclerosing cholangitis: a systematic review and meta-analysis. Hepatology 2011; 53: 1590-9.

6. Bambha K, Kim WR, Talwalkar J, Torgerson H, Benson JT, Therneau TM, et al. Incidence, clinical spectrum, and outcomes of primary sclerosing cholangitis in a United States community. Gastroenterol 2003; 125: 1364-9.

7. Kingham JG, Kochar N, Gravenor MB. Incidence, clinical patterns, and outcomes of primary sclerosing cholangitis in South Wales, United Kingdom. Gastroenterol 2004; 126 : 1929-30.

8. Kaplan GG, Laupland KB, Butzner D, Urbanski SJ, Lee SS. The burden of large and small duct primary sclerosing cholangitis in adults and children: a population-based analysis. Am J Gastroenterol 2007; 102: 1042-9.
9. Card TR, Solaymani-Dodaran M, West J. Incidence and mortality of primary sclerosing cholangitis in the UK: a population-based cohort study. J Hepatol 2008; 48: 939-44.

10. Lindkvist B, Benito de Valle M, Gullberg B, Björnsson E. Incidence and prevalence of primary sclerosing cholangitis in a defined adult population in Sweden. Hepatology 2010; 52: 571-7.

11. Boberg KM, Aadland E, Jahnsen J, Raknerud N, Stiris $\mathrm{M}$, Bell $\mathrm{H}$. Incidence and prevalence of primary biliary cirrhosis, primary sclerosing cholangitis, and autoimmune hepatitis in a Norwegian population. Scand J Gastroenterol 1998; 33: 99-103.

12. Vefsíða Hagstofu Íslands, hagstofa.is - febrúar 2017.

13. Krabbameinsskrá Krabbameinsfélags Íslands, krabbameinsskra.is - september 2018.

14. Schrumpf E, Boberg KM, Karlsen TH. Primary sclerosing cholangitis - the Norwegian experience. Scand J Gastroenterol 2015; 50: 781-96.

15. Björnsson E, Olsson R, Bergquist A, Lindgren S, Braden $\mathrm{B}$, Chapman RW, et al. The natural history of small-duct primary sclerosing cholangitis. Gastroenterol 2008; 134: 975-80.

16. Lindor KD. Ursodiol for primary sclerosing cholangitis. Mayo Primary Sclerosing Cholangitis-Ursodeoxycholic Acid Study Group. N Engl J Med 1997; 336: 691-5.

17. Lindor KD, Kowdley KV, Luketic VA, Harrison ME, McCashland T, Befeler AS, et al. High-dose ursodeoxycholic acid for the treatment of primary sclerosing cholangitis. Hepatology 2009; 50: 808-14.
18. EASL Clinical Practice Guidelines: The diagnosis and management of patients with primary biliary cholangitis. J Hepatol 2017; 67: 145-72.

19. de Valle MB, Björnsson E, Lindkvist B. Mortality and cancer risk related to primary sclerosing cholangitis in a Swedish population-based cohort. Liver Int 2012; 32: 4418.

20. EASL Clinical Practice Guidelines: management of cholestatic liver diseases. J Hepatol 2009; 51: 237-67.

21. Kornfeld D, Ekbom A, Ihre T. Is there an excess risk for colorectal cancer in patients with ulcerative colitis and concomitant primary sclerosing cholangitis? A population based study. Gut 1997; 41: 522-5.

22. Brandsaeter $B$, Isoniemi $H$ Broome $U$, Olausson $M$ Backman L, Hansen B, et al. Liver transplantation for primary sclerosing cholangitis; predictors and consequences of hepatobiliary malignancy. J Hepatol 2004; 40: 815-22.

23. Broome U, Olsson R, Loof L, Bodemar G, Hultcrantz R, Danielsson A, et al. Natural history and prognostic factors in 305 Swedish patients with primary sclerosing cholangitis. Gut 1996 ; 38 : 610-5.

24. Rosen CB, Nagorney DM, Wiesner RH, Coffey RJ, Jr. LaRusso NF. Cholangiocarcinoma complicating primary sclerosing cholangitis. Ann Surg 1991; 213: 21-5. 


\section{Primary sclerosing cholangitis in Iceland 1992-2012}

\author{
Hafsteinn Óli Guðnason' \\ Jón Örvar Kristinsson' \\ Óttar Már Bergmann ${ }^{1}$ \\ Sigurður Ólafsson ${ }^{1}$ \\ Jón Gunnlaugur Jónasson ${ }^{2,3}$ \\ Einar Stefán Björnsson ${ }^{1}$
}

Background: Primary sclerosing cholangitis (PSC) is a chronic cholestatic disease affecting the intra- and/or extrahepatic biliary tree with inflammation and progressive stricture formation that can lead to cirrhosis, end stage liver failure and liver transplantation. Known risk factors include inflammatory bowel diseases (IBD), mainly ulcerative colitis (UC). Highest reported incidence in an adult population is 1.2$1.3 / 100.000$ in Norway and Sweden, where $60-76 \%$ have IBD. The aim of this study was to investigate epidemiology of PSC in Iceland in the years 1992 to 2012 and the patients outcomes.

Methods: A search for the diagnosis "cholangitis" (ICD-10, K83.0) was performed in the database for hospital records in Landspitali (The National University Hospital of Iceland, LSH) and Akureyri Hospital from 1992 to 2012. We also looked through all ERCP and MRCP imaging done in LSH in the same period along with a text search in both the hospital records and the pathology database for liver biopsies. Data on these patients was collected until the end of 2016.
Results: A total of 42 patient got the diagnosis PSC within the period. Median age at diagnosis was 34 years, $67 \%$ were male and $90 \%$ adults ( $\geq 18$ years old). Mean incidence per year was $0.69 / 100.000$. Overall $88 \%$ of patients had IBD, thereof $89 \%$ UC. Seven patients have been diagnosed with cancer, four with cancer in the bile ducts and one in the gallbladder. Within the study period a total of five patients died $(12 \%)$, 51 months (median) from diagnosis and three from cholangiocarcinoma, 51 months (median) from diagnosis. Three patients (7\%) underwent liver transplantation, one required a transplant two times.

Conclusions: The incidence of PSC in Iceland turned out to be lower than in our neighbouring countries in Scandinavia. It is unclear if this is due to underdiagnosis or, more likely, that PSC is simply more uncommon in Iceland. Overall $7 \%$ underwent liver transplantation and $12 \%$ died within the study period, main cause of mortality being cholangiocarcinoma.

${ }^{1}$ Department of Internal Medicine, Division of Gastroenterology, Landspitali University Hospital, Reykjavík, Iceland, ${ }^{2}$ Department of Pathology, Landspitali University Hospital, Reykjavik, Iceland, ${ }^{3}$ Faculty of Medicine, University of Iceland, Reykjavík, Iceland.

Key words: PSC, primary sclerosing cholangitis, epidemiology, incidence, sclerosing cholangitis.

Correspondence: Hafsteinn Óli Guð̃nason, haddiog@gmail.com 